\title{
ANALISIS POTENSI PAD PROVINSI SUMATERA SELATAN
}

\author{
Endang Kusdiah Ningsih ${ }^{1)}$ \\ Universitas IBA Palembang \\ endanghasan62@gmail.com
}

\author{
Dwi Eka Novianty ${ }^{2)}$ \\ Universitas IBA Palembang \\ dwiekan@gmail.com
}

\begin{abstract}
Optimizing management of regional economic potential is an effort to increase Own-Source Revenue (PAD) as a form of building regional financial independence so that it can reduce fiscal dependence on the central government. This study analyzes each component of PAD that can contribute to increasing PAD by using Klassen Typology. This Klassen Typology Analysis is conducted to find out the types of PAD components that fall into the advanced, advanced, depressed, potential or backward categories. The data used in this study are secondary data in the form of South Sumatra Province PAD data as an analysis area and national PAD as a reference area. The data analyzed are data from 2014-2018. The results showed that local taxes are in quadrant I of the Klassen Typology, a quadrant which explains that local taxes are a component of advanced and rapid PAD with the largest contribution of 93.53\%.Furthermore, the other components of PAD, namely regional retribution, the results of the management of regional wealth and other legitimate PAD, are in quadrant III. This quadrant explains that the component of PAD is potential or can still be developed again. These results explain that the government of South Sumatra Province to further improve the management of regional user fees, the results of the management of regional wealth and other PAD in order to finance development using their own funds.
\end{abstract}

Keywords: Own-Source Revenue, Klassen

Competitive Jurnal Akuntansi dan Keuangan, Vol. 4 (No.2),E-ISSN 2549-79IX 


\section{PENDAHULUAN}

Undang-Undang Nomor 22 tahun 1999 tentang Pemerintah daerah merupakan payung hukum dilaksanakannya otonomi daerah secara luas, nyata dan bertanggungjawab. Untuk itu diperlukan kewenangan dan kemampuan derah untuk menggali sumber keuangan sendiri dan ini didukung oleh Undang-Undang No.33 tahun 2004 tentang Perimbangan Keuangan antara Pemerintah Pusat dan Pemerintah Daerah.

Kedua undang-undang tersebut, telah menjamin pemerintah daerah dalam melakukan usaha-usaha peningkatan kemampuan keuangan sendiri yaitu peningkatan Pendapatan Asli Daerah(PAD) baik yang sudah ada maupun penggalian sumber PAD yang baru sesuai dengan kondisi dan potensi ekonomi masyarakat.

Pendapatan Asli Daerah (PAD) adalah penerimaan yang diperoleh dari sumbersumber pendapatan di dalam daerahnya sendiri. Pendapatan Asli Daerah tersebut dipungut berdasarkan peraturan daerah yang sesuai dengan peraturan perundang-undangan yang berlaku di Indonesia. Undang-undang No.33 tahun 2004 menyatakan bahwa sumber-sumber PAD adalah (1) Pajak Daerah yaitu kontribusi wajib kepada daerah yang terutang oleh orang pribadi atau badan yang bersifat memaksa berdasarkan undang-undang dengan tidak mendapatkan imbalan secara langsung dan digunakan untuk keperluan daerah bagi sebesar-besarnya kemakmuran rakyat.Pengertian tersebut termuat di dalam Undang-undang Pajak Daerah dan Retribusi Daerah Nomor 28 Tahun 2009, (2) Retribusi Daerah yaitu pembayaran yang dilakukan oleh masyarakat kepada daerah atas pelayanan yang diterima secara langsung atau atas perizinan yang diperoleh. Berbeda dengan pajak yang dikenakan tidak berdasarkan pelayanan langsung, retribusi hanya dapat dikenakan apabila pemerintah daerah memberikan pelayanan secara langsung kepada masyarakat atau pemerintah daerah memberikan izin untuk melaksanakan kegiatan tertentu, (3) Hasil perusahaan milik daerah dan hasil pengelolaan kekayaan milik daerah yang dipisahkan yaitu Penerimaan daerah yang berasal dari hasil perusahaan milik daerah dan pengelolaan kekayaan milik daerah yang dipisahkan. Perusahaan daerah adalah semua perusahaan yang didirikan dengan modal daerah baik seluruhnya ataupun sebagian dan (4) Lain-lain pendapatan asli daerah sah meliputi hasil penjualan kekayaan daerah yang tidak dipisahkan, Jasa giro, Pendapatan Bunga, Keuntungan selisih nilai tukar rupiah terhadap matauang asing serta Komisi, potongan, ataupun bentuk lain sebagai akibat dari penjualan atau pengadaan barang dan jasa oleh daerah

.PAD merupakan cermin dari kemandirian suatu daerah didalam mengelola keuangan daerah. Kemandirian keuangan daerah dapat diukur melalui rasio kemandirian yaitu membandingkan realisasi penerimaan PAD dengan penerimaan transfer dari pusat. Rasio kemandirian keuangan daerah merupakan gambaran tingkat ketergantungan pemerintah daerah terhadap pemerintah pusat. Semakin tinggi rasio kemandirian, maka semakin rendah tingkat ketergantungan daerah tersebut terhadap pemerintah pusat. Penelitian yang dilakukan Tarmizi (2010), menjelaskan bahwa PAD berdampak terhadap kemandirian keuangan daerah.

Kemandirian keuangan merupakan indikator keberhasilan dalam pelaksanaan otonomi daerah dalam pembangunan dan pemerataan ekonomi daerah.Otonomi daerah diasumsikan merupakan cara terbaik dalam mendorong pembangunan daerah. Keberhasilan pembanguan suatu daerah dapat diukur melalui laju pertumbuhan ekonomi daerah tersebut. Untuk mengukur kemampuan keuangan daerah dalam membiayai pengeluaran daerah dapat diukur melalui kontribusi masing-masing sumber atau komponen PAD.

Penelitian Suci, et,al, (2014) secara empiris menunjukkan bahwa kemandirian keuangan daerah berpengaruh positif terhadap pertumbuhan ekonomi di provinsi Banten. Hasil penelitian ini berbeda dengan penelitian yang dilakukan oleh Putra,et.al (2016) menunjukkan bahwa tidak terdapat hubungan yang signifikan antara rasio-rasio kemandirian keuangan daerah (derajat desentralisasi fiskal, rasio ketergantungan, rasio kemandirian dan 
efektifitas PAD) dengan pertumbuhan ekonomi provinsi Jambi.

Rasio kemandirian, pola hubungan dan kemampuan keuangan daerah provinsi Sumatera Selatan dari tahun 2013-2018, terlihat pada tabel 1, berikut ini :

Tabel.1

Rasio Kemandirian Keuangan Daerah Provinsi Sumatera Selatan 2013-2018

\begin{tabular}{|c|l|l|l|l|l|}
\hline $\begin{array}{c}\text { Tah } \\
\text { un }\end{array}$ & $\begin{array}{l}\text { PAD } \\
\text { (milyar/ } \\
\text { Rp) }\end{array}$ & $\begin{array}{l}\text { Penerim } \\
\text { aan } \\
\text { Tranfer } \\
\text { dari } \\
\text { Pusat } \\
\text { (milyar/ } \\
\text { Rp) }\end{array}$ & $\begin{array}{l}\text { Rasio } \\
\text { Kemandi } \\
\text { rian (\%) }\end{array}$ & $\begin{array}{l}\text { Pola } \\
\text { Hubung } \\
\text { an }\end{array}$ & $\begin{array}{l}\text { Kemamp } \\
\text { uan } \\
\text { Keuanga } \\
n\end{array}$ \\
\hline $\begin{array}{c}201 \\
3\end{array}$ & 2026,51 & 1882,15 & 107,67 & $\begin{array}{l}\text { Delegat } \\
\text { if }\end{array}$ & Tinggi \\
\hline $\begin{array}{c}201 \\
4\end{array}$ & 1080,59 & 1827,14 & 59,14 & $\begin{array}{c}\text { Partisip } \\
\text { atif }\end{array}$ & Sedang \\
\hline $\begin{array}{c}201 \\
5\end{array}$ & 1876,80 & 2947,90 & 63,66 & $\begin{array}{c}\text { Partisip } \\
\text { atif }\end{array}$ & Sedang \\
\hline $\begin{array}{c}201 \\
6\end{array}$ & 1771,70 & 2911,60 & 60,85 & $\begin{array}{c}\text { Partisip } \\
\text { atif }\end{array}$ & Sedang \\
\hline $\begin{array}{c}201 \\
7\end{array}$ & 1268,40 & 3072,90 & 41,28 & $\begin{array}{c}\text { Konsult } \\
\text { atif }\end{array}$ & Rendah \\
\hline $\begin{array}{c}201 \\
8\end{array}$ & 1602,10 & 2736,90 & 58,54 & $\begin{array}{c}\text { Partisip } \\
\text { atif }\end{array}$ & Sedang \\
\hline
\end{tabular}

Sumber : KEK BI, 2019

Rasio kemandirian keuangan daerah provinsi Sumatera Selatan rata-rata sebesar 65,19\% selama periode 2013-2018. Tahun 2013, rasio kemandirian sebesar 107,67\%, berarti kemampuan keuangan provinsi Sumatera Selatan tinggi dengan pola hubungan delegatif. Pola hubungan delegatif yaitu pola hubungan dimana campur tangan pemerintah pusat sudah tidak ada karena daerah telah benar-benar mampu dan mandiri dalam melaksanakan otonomi daerah (Halim, 2004 $\mathrm{p}: 189)$.

Akan tetapi untuk tahun selanjutnya terjadi penurunan rasio kemandirian, ini berarti kemampuan keuangan daerah sedang bahkan rendah di tahun 2017. Pola hubungan yang terjadi juga mengalami penurunan menjadi partisipatif bahkan di tahun 2017 menjadi konsultatif. Pola hubungan keuangan daerah kategori partisipatif, artinya peran pemerintah pusat semakin berkurang, mengingat daerah yang bersangkutan tingkat kemandiriannya mendekati mampu melaksanakan otonomi.
Sementara, pola hubungan konsultatif artinya campur tangan pemerintah pusat berkurang serta lebih banyak memberikan konsultasi.

Perubahan kemampuan keuangan daerah yang fluktuatif tersebut tidak terlepas dari kontribusi masing-masing komponen PAD. Kontribusi komponen PAD Propinsi Sumatera Selatan tahun 2017 adalah : Pajak Daerah (93,53\%), Retribusi Daerah (0,51\%), Hasil Pengelolaan Kekayaan Daerah $(1,84 \%)$ dan Lain-lain PAD yang Sah $(4,12 \%)$.

Pajak Daerah memberikan kontribusi terbesar, sedangkan retribusi daerah memberikan kontribusi terkecil, seperti pada gambar 1 berikut ini :

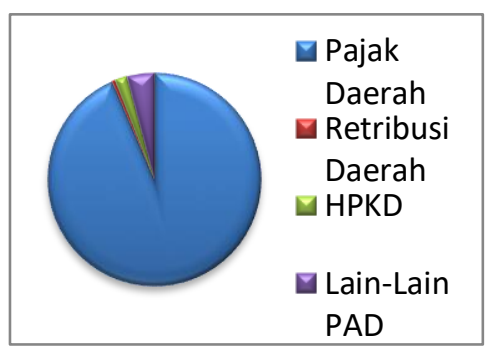

$$
\text { Gambar } 1
$$

Kontribusi Komponen PAD

Provinsi Sumatera Selatan

Tahun 2014-2018

\section{KAJIAN PUSTAKA PENGEMBANGAN HIPOTESIS}

DAN

Kemampuan keuangan daerah dalam membiayai pengeluaran daerah dapat dilihat melalui besarnya kontribusi masing-masing komponen PAD. Oleh karena itu kemandirian keuangan daerah dapat terealisasi apabila pemerintah mampu menggali sumber-sumber PAD secara optimal sebagai sumber pembiayaan pembangunan daerah.

Tujuan penelitian ini adalah untuk mengetahui gambaran tentang pola dan struktur pertumbuhan semua komponen PAD dengan menggunakan analisis tipologi Klassen.

Kusmayanti,et.al,(2018) menganalisis potensi PAD menggunakan tipologi Klassen, dan hasil penelitian dapat menunjukkan potensi sumber PAD melalui sektor-sektor ekonomi yang potensial pada pada setiap kabupaten di Bali. Selanjutnya, hasil penelitian Syaifuddin, et,al, ( 2014 ), menyatakan bahwa suatu daerah dapat melakukan pemetaan potensi pendapatan 
daerah dengan menggunakan tipologi Klassen. Penggunaan analisis tipologi Klassen untuk memetakan sektor ekonomi unggulan pada kabupaten/kota provinsi Sumatera Selatan, telah dilakukan oleh Saputri, et.al, (2018).

Analisis potensi PAD yang dilakukan dalam penelitian ini, berbeda dibandingkan dengan penelitian sebelumnya. Dalam penelitian penggunakan tipologi Klassen adalah untuk memetakan kuadran dari setiap komponen PAD, yaitu pajak daerah, retribusi daerah, hasil pengelolaan kekayaan daerah dan lain-lain PAD yang sah.

Analisis tipologi Klassen merupakan suatu alat analisis yang digunakan untuk mengetahui gambaran tentang pola dan struktur pertumbuhan suatu sektor, sub sektor, usaha atau komoditi daerah. Tipologi Klassen memiliki empat kuadran dengan karakteristik berbeda dalam bentuk matrix, seperti yang terlihat pada tabel 2 berikut ini :

Tabel 2

Matrix Tipologi Klassen

\begin{tabular}{|c|c|c|}
\hline $\begin{array}{c}\text { Kontribusi } \\
\text { Komponen } \\
\text { PAD }\end{array}$ & \multicolumn{2}{|c|}{ Pertumbuhan Komponen PAD } \\
\cline { 2 - 3 } ci $>=\mathrm{c}$ & $\begin{array}{c}\text { Maju dan } \\
\text { pesta tumbuh }\end{array}$ & $\begin{array}{c}\text { Maju dan } \\
\text { tertekan }\end{array}$ \\
\hline $\mathrm{ci}<\mathrm{c}$ & $\begin{array}{c}\text { Potensial atau } \\
\text { dapat } \\
\text { dikembangan }\end{array}$ & $\begin{array}{c}\text { Relatif } \\
\text { Tertinggal }\end{array}$ \\
\hline
\end{tabular}

Sumber : Junaidi,2010 (dimodifikasi)

Keterangan :

gi $=$ Pertumbuhan komponen $\mathrm{PAD}$ daerah analisis

$\mathrm{g}=$ Pertumbuhan komponen $\mathrm{PAD}$ daerah acuan

$\mathrm{ci}=$ Kontribusi komponen PAD daerah analisis

$\mathrm{c}=$ Kontribusi komponen PAD daerah acuan

Daerah acuan adalah daerah yang lebih tinggi. Dalam penelitian ini daerah analisis adalah propinsi Sumatera Selatan, sedangkan daerah acuan adalah nasional.

Tipologi Klassen mempunyai empat klasifikasi dengan karakteristik yang berbeda satu sama lain, yaitu :
(1). Kuadran I merupakan kuadran dengan laju sektor pertumbuhan komponen PAD lebih besar dibandingkan dengan laju pertumbuhan daerah acuan dan memiliki kontribusi komponen PAD lebih besar dari kontribusi daerah acuan. Pada kuadran ini, komponen PAD mengalami kemajuan dan tumbuh pesat.

(2). Kuadran II merupakan kuadran dengan laju sektor pertumbuhan komponen PAD lebih rendah dibandingakan pertumbuhan komponen PAD daerah acuan, dengan kontribusi lebih besar dari kontribusi daerah acuan. Komponen PAD pada kuadran ini mengalami kemajuan tetapi tertekan atau sektor yang telah jenuh.

(3). Kuadran III merupakan kuadran dengan laju pertumbuhan komponen PAD lebih besar dibandingkan pertumbuhan daerah acuan tetapi kontribusi lebih komponen PAD lebih kecil dibandingkan kontribusi daerah acuan. Komponen PAD pada kuadran ini merupakan sektor yang potensial atau masih dapat dikembangkan.

(4) Kuadran IV merupakan kuadran dengan pertumbuhan dan kontribusi konponen PAD lebih kecila dibandingkan dengan pertumbuhan dan kontribusi komponen PAD daerah acuan. Pada kuadran ini, dapat dikatakan bahwa komponen PAD merupakan sektor yang relatif tertinggal.

\section{METODE PENELITIAN}

Penelitian di lakukan di provinsi Sumatera Selatan dengan periode waktu 2013 2018.

Data yang digunakan dalam penelitian ini adalah data sekunder yaitu data Pendapatan Asli Daerah (PAD) provinsi Sumatera Selatan yang bersumber dari Kajian Ekonomi Keuangan Bank Indonesia dan teknik analisis yang digunakan adalah Analisis Tipologi Klassen.

\section{HASIL DAN PEMBAHASAN}

Hasil perhitungan tipologi Klassen terhadap potensi komponen PAD provinsi 
Sumatera Selatan sebagai daerah analisis dan komponen PAD tingkat nasional sebagai acuan, secara terinci diperlihatkan pada tabel 3 berikut ini :

Tabel 3

Hasil Perhitungan Tipologi Klassen

\begin{tabular}{|c|c|c|c|c|}
\hline \multirow{2}{*}{$\begin{array}{c}\text { Komp } \\
\text { onen }\end{array}$} & \multicolumn{2}{|c|}{$\begin{array}{c}\text { Daerah Analisis } \\
\text { Provinsi } \\
\text { PAmatera Selatan }\end{array}$} & \multicolumn{2}{|c|}{$\begin{array}{c}\text { Daerah Acuan } \\
\text { Nasional }\end{array}$} \\
\cline { 2 - 5 } & $\begin{array}{c}\text { Rata- } \\
\text { rata } \\
\text { Pertumb } \\
\text { uhan } \\
(\%)\end{array}$ & $\begin{array}{c}\text { Rata } \\
\text {-rata } \\
\text { Kontri } \\
\text { busi } \\
(\%)\end{array}$ & $\begin{array}{c}\text { Rata- } \\
\text { rata } \\
\text { Pertumb } \\
\text { uhan } \\
(\%)\end{array}$ & $\begin{array}{c}\text { Rata } \\
\text { Konta } \\
\text { busi } \\
(\%)\end{array}$ \\
\hline $\begin{array}{c}\text { Pajak } \\
\text { Daerah }\end{array}$ & 11,98 & 92,74 & 8,31 & 84,80 \\
\hline $\begin{array}{c}\text { Retrib } \\
\text { usi } \\
\text { Daerah }\end{array}$ & 17,86 & 0,65 & 9,40 & 1,30 \\
\hline $\begin{array}{c}\text { Hasil } \\
\text { PKD }\end{array}$ & 18,15 & 2,22 & 7,32 & 2,52 \\
\hline $\begin{array}{c}\text { Lain- } \\
\text { lain }\end{array}$ & 14,11 & 3,73 & 11,10 & 11,40 \\
PAD & & & & \\
\hline
\end{tabular}

Sumber : data diolah,2019

Rata-rata pertumbuhan Hasil Pengeloaan Kekayaan Daerah (HPK) tertinggi yaitu sebesar $18,15 \%$ dibandingakan retribusi daerah dengan pertumbuhan $17,86 \%$. Selanjutnya, rata-rata pertumbuhan lain-lain PAD sebesar $14,11 \%$ lebih tinggi dibandingkan dengan rata-rata $11,98 \%$, terendah diantara semua komponen PAD. pertumbuhan pajak daerah yang hanya sebesar untuk daerah analisis yaitu provinsi Sumatera Selatan.

Komponen PAD yang memberikan rata-rata kontribusi terbesar adalah pajak daerah yaitu sebesar 92,74\%, sementara komponen Lain-lain PAD yang Sah memberikan rata-rata kontribusi $3,73 \%$. Untuk komponen yang lain, yaitu Hasil Pengelolaan Kekayaan Daerah dan retribusi daerah masingmasing mempunyai rata-rata kontribusi sebesar $2,22 \%$ dan $0,65 \%$.

Secara nasional, rata-rata pertumbuhan Lain-lain PAD yang Sah sebesar 11,10\% lebih tinggi dibandingkan dengan rata-rata pertumbuhan komponen PAD yang lain yaitu retribusi daerah, pajak daerah dan Hasil Pengelolaan Kekayaan Daerah, masing-masing sebesar 9,40\%, 8,31\% dan 7,32\%. Hasil Pengelolaan Kekayaan Daerah merupakan komponen PAD dengan rata-rata pertumbuhan yang paling rendah.

Pajak daerah memberikan rata-rata kontribusi terbesar secara nasional, yaitu $84,80 \%$, sedangkan rata-rata kontribusi terbesar setalah pajak daerah adalah Lain-lain PAD yang Sah, yaitu 11,40\%. Untuk komponen PAD yang lain, Hasil Pengelolaan Kekayaan Daerah, memberikan rata-rata kontribusi sebesar $2,52 \%$. Rata-rata kontribusi terendah adalah retribusi daerah sebesar $1,30 \%$.

Apabila rata-rata pertumbuhan dibandingkan antara daerah analisis dan daerah acuan untuk masing-masing komponen PAD, maka diperoleh hasil sebagai berikut :

1. Rata-rata pertumbuhan pajak daerah provinsi Sumatera Selatan lebih tinggi dari rata-rata pertumbuhan pajak daerah tingkat nasional.

2. Rata-rata pertumbuhan retribusi daerah provinsi Sumatera Selatan lebih tinggi dari rata-rata pertumbuhan retribusi daerah secara nasional.

3. Rata-rata pertumbuhan Hasil pengelolaan Kekayaan Daerah provinsi Sumatera Selatan juga lebih tinggi dari rata-rata pertumbuhan Hasil Pengelolaan Kekayaan Daerah secara nasional.

4. Rata-rata pertumbuhan Lain-lain PAD yang sahprovinsi Sumatera Selatan lebih tinggi dari Lain-lain PAD yang Sah secara nasional.

Untuk rata-rata kontribusi komponen $\mathrm{PAD}$, perbandingan antara daerah analisis dan daeraah acuan adalah sebagai berikut :

1. Rata-rata kontribusi pajak daerah provinsi Sumatera Selatan lebih tinggi dari rata-rata kontribusi pajak daerah secara nasional.

2. Rata-rata kontribusi retribusi daerah provinsi Sumatera Selatan lebih rendah dari rata-rata kontribusi retribus nasional.

3. Rata-rata kontribusi Hasil Pengelolaan Kekayaan daerah provinsi Sumatera Selatan lebih rendah dari rata-rata kontribusi Hasil Peneglolaan Kekayaan Daerah nasional.

4. Rata-rata kontribusi Lain-lain PAD provinsi Sumatera Selatan juga lebih rendah 
dari rata-rata kontribusi Lain-lain PAD secara nasional.

Untuk mengetahui potensi komponen PAD , digunakan tipologi Klassen, dan berdasarkan perhitungan dari tabel 3, maka diperoleh matrix sebagai berikut :

\section{Tabel 4}

Matrix Tipologi Klassen

Komponen PAD Provinsi Sumatera Selatan

\begin{tabular}{|c|l|c|}
\hline $\begin{array}{c}\text { Kontribusi } \\
\text { Komponen } \\
\text { PAD }\end{array}$ & \multicolumn{2}{|c|}{ Pertumbuhan Komponen PAD } \\
\cline { 2 - 3 } ci $>=\mathrm{c}$ & \multicolumn{1}{|c|}{ Pajak Daerah } & gi $<\mathrm{g}$ \\
\hline & $\begin{array}{l}\text { a. Retribusi } \\
\text { Daerah } \\
\text { b. Hasil } \\
\text { ci }<\mathrm{c}\end{array}$ & $\begin{array}{l}\text { Pengelolaan } \\
\text { Kekayaan } \\
\text { Daerah } \\
\text { c. Lain-lain PAD } \\
\text { yang Sah }\end{array}$ \\
\hline
\end{tabular}

Sumber : data diolah, 2019

Berdasarkan hasil analisis diatas, maka komponen PAD provinsi Sumatera Selatan terkelompokan menjadi 2 (dua) kuadran, yaitu

1. Kuadran I, yaitu komponen PAD yang maju dan tumbuh pesat adalah Pajak Daerah yang memberikan kontribusi paling tinggi terhadap PAD sebesar 93,53\% . Ini menunjukkan bahwa pajak daerah merupakan komponen unggulan dari PAD yang harus dipertahankan bahkan bisa ditingkatkan lagi.

Hasil penelitian yang dilakukan oleh Setiono (2018), juga memberikan hasil yang sama bahwa pajak daerah memberikan kontribusi paling besar yaitu $83,49 \%$ untuk PAD provinsi Jawa Timur.

Penelitian yang dilakukan oleh Riftiasari (2018), juga memberikan hasil sama, yaitu kontribusi pajak darah terhadap PAD provinsi DKI Jakarta sebesar 84,74\%.

Tingginya kontribusi pajak daerah terhadap PAD,ini menurut Nasir (2019) karena didukung oleh pemberlakuan Undang-
Undang nomor 28 tahun 2009 tentang Pajak dan Retribusi Daerah, sehingga penerimaan dari sektor pajak semakin meningkat karena kewenangan yang dimiliki semakin luas dan jenis pajak yang dipungut bertambah. Pertambahan jenis pajak tersebut meliputi 3 (tiga) jenis pajak kabupaten/kota yang baru yaitu PBB Pedesaan dan Perkotaan, BPHTB dan Pajak Sarang Burung Walet.

Hasil berbeda peroleh dari penelitian yang dilakukan oleh Sulistiyanto (2018), bahwa pajak daerah hanya memberikan kontribusi sebesar $4,4 \%$ terhadap PAD provinsi Jawa Tengah.

Perbedaan dalam besaran kontribusi pajak daerah ini karena setiap daerah memiliki potensi sumber pajak daerah dan jenis pajak yang berbeda sehingga untuk meningkatkan pajak daerah dibutuhkan strategi yang berbeda pula.

2. Kuadran III, yaitu komponen PAD yang potensial atau masih mempunyai ruang yang besar untuk dikembangkan adalah retribusi daerah, hasil pengelolaan kekayaan daerah dan lain-lain PAD yang sah. Kontribusi terhadap PAD dari ke 3 (tiga) komponen tersebut masih relatif, dibawah $5 \%$. Bahkan untuk retribusi daerah hanya menyumbang sebesar $0,51 \%$.

Hasil penelitian yang dilakukan oleh Nasir (2019), menunjukkan bahwa kontribusi retribusi daerah terhadap PAD kabupaten/kota seluruh Indonesia tahun 2007-2012 rata-rata sebesar 19\% lebih rendah dibandingkan dengan pajak daerah dan Lain-lain PAD yang Sah.

Lakoy, et.al (2016), melakukan penelitian tentang pengaruh retribusi daerah terhadap PAD di Kabupaten Minahasa Selatan, dan hasil yang diperolah dari uji signifikansi bahwa retribusi daerah tidak berpengaruh secara signifikan terhadap PAD. Walaupun rata-rarat kontribusi retribusi daerah selama kurun waktu 2005-2014 relatif besar yaitu $25,29 \%$.

Penelitian yang dilakukan oleh Tresnawati,et.al (2017), menyatakan bahwa kontribusi rata-rata retribus daerah terhadap PAD kota Bandung selama periode 20112015, hanya sebesar 7,30\%. 
Penelitian-penelitian tentang retribusi daerah tersebut, menjelaskan bawah pengelolaan retribusi daerah sebagai salah satu komponen PAD belum optimal dan masih dapat ditingkatkan. Untuk itu daerah harus dapat memberikan pelayanan yang baik dan berkualitas kepada masyarakat. Ini dikarenakan retribusi memiliki sifat iuran berdasarkan pelayanan jasa yang diberikan daerah langsung kepada masyarakat yang mendapat manfaat.

Untuk mengoptimalkan penerimaan retribusi daerah, terlebih dahulu dipahami tentang prinsip umum retribusi yang efisien. Menurut Fisher (1996, dalam Kurniawan, 2009), bahwa prinsip umum retribusi yang efisien adalah :

a. Pembiayaan retribusi menjadi lebih menarik sebagai akibat dari peningkatan keuntungan margin dari pengguna langsung.

b. Pembiayaan retribusi membutuhkan kondisi bahwa pengguna langsung dapat dengan mudah diidentifikasi dan dikecualikan (pada biaya yang pantas) dari mengkonsumsi pelayanan kecuali apabila harga dibayar, dengan asumsi bahwa kebanyakan keutungan dari sebuah pelayanan atau fasilitas diterima oleh pengguna langsung.

c. Kasus efisiensi bagi pembiayaan retribusi lebih kuat ketika permintaan lebih elastis harganya.

d. Keuntungan margin dan bukan keuntungan total sangat berpengaruh dalam menentukan retribusi.

Kementerian Keuangan Republik Indonesia, melalui Direktorat Jenderal Perimbangan keuangan (2019) telah membuat strategi peningkatan pajak daerah dan retribusi daerah, yaitu : melalui intensifikasi dan optimaslisasi pajak daerah dan retribus daerah dengan cara :

a. pemanfaatan teknologi informasi, mutlak diperlukan karena sistem pemungutan pajak/retribusi cenderung tidak optimal.

b. memperluas basis penerimaan dengan cara mengidentifikasi pembayar pajak /retribusi baru/potensial, serta memperbaiki basis data objek, memperbaiki penilaian, menghitung kapasitas penerimaan dari setiap jenis pungutan.

c. memperkuat proses pemungutan, dengan tujuan untuk menyempurnakan perda, mengubah tarif dan meningkatkan kualitas sumber daya manusia.

Penerapan otonomi daerah telah memasuki tahun ke -20 atau 2 dasawarsa, namun permasalah dalam peningkatan PAD tetap sama di sejumlah daerah tidak terkecuali provinsi Sumatera Selatan. Permasalahan tersebut menurut Firdausy (2017) adalah : Pertama, umumnya pemerintah daerah belum mampu mendidentifikasi potensi sumber pendapatan. Kedua, sebagian besar daerah belum dapat mengoptimalkan penerimaan pajak daerah, retribusi daerah atau bahkan penerimaan dari hasil kekayaan daerah yang dipisahkan sesuai dengan UU No.33 Tahun 2004 tentang Perimnbangan Keuangan Pusat dan Daerah. Ketiga, daerah masih menganggap bahwa rendahnya PAD sebagai akibat dari euang gerak daerah yang terbatas untuk mengoptimalkan penerimaan pajak daerah dan retribusi daerah sebagaimana diatur dalam UU No.28 Tahun 2009. Keempat, daerah masih melihat bahwa potensi pendapatan pajak yang besar masih diatur oleh pusat, yaituPajak Penghasila, Pajak Pertambahan Nilai dan Pajak Rokok. Kelima, Kesiapan Sumber Daya Manuasia (SDM), baik dalam kuantitas maupun dalam kualitas. Keenam, lemahnya pengawasan atas pelaksanaan pemungutan pajak daerah dan retribusi daerah.

\section{SIMPULAN}

Berdasarkan hasil penelitian dan pembahasan tentang potensi PAD provinsi Sumatera Selatan, maka diperoleh simpulan sebagai berikut :

1. Pajak daerah berada dalam kuadran I dari matrisx tipologi Klassen, berarti komponen ini merupakan komponen yang telah maju dan tumbuh pesat dan memberikan kontribusi tersbesar terhadap PAD.

2. Retribusi daerah, hasil pengelolaan kekayaan daerah dan lain-lain PAD yang sah, berada pada kuadran III, artinya komponenkomponen masih sangat potensal untuk 
dikembangkan. Terutama komponen retribusi daerah dengan kontribusi paling kecil terhadap PAD.

Keterbatasan penelitian ini, tidak menganalisis potensi dari setiap komponen dari pajak daerah dan retribusi daerah.

\section{DaftarPustaka}

Bank Indonesia.2019. Kajian Ekonomi Keuangan Propinsi Sumatera Selatan. Diakses dari https://www.bi.go.id , publikasi , kajian-ekonomi-regional , sumsel

Firdausy, Carunia Mulya (editor).2017. Kebijakan dan Strategi Peningkatan Pendapatan Asli Daerah Dalam Pembangunan Nasional. Yayasan Pustaka Obor Indonesia. Jakarta

Halim, Abdul.2004. Akuntansi Keuangan Daerah. Salemba Empat. Jakarta

Junaidi, Chaniago. 2010. Mengenai Tipologi Klassen(Seri 1. Analisis Ekonomi Daerah). Diakses dari https://junaidichaniago.wordpress.com/201 0/02/14/mengenal-tipologi-klassen-seri-1analisis-ekonomi-daerah/

Kementerian Keuangan Republik Indonesia, Direktorat Jenderal Perimbangan Keuangan. 2019. Strategi Peningkatan Pajak Daerah dan Retribusi Daerah. Diakses dari

keuda.kemendagri.go.id > asset > kcfinder > upload > files > Bahan Strateg.

Kurniawan, Teguh.2009. Isu dan Masalah dalam Upaya Menggali Potensi Pajak/Retribusi Daerah dari Sektor Informal. Seminar Satu Hari " Menggali Potensi Pajak dari PKL di Jakarta dan Bandung: Kesempatan dan Tantangan. Sekolah Tinggi Kesejahteraan Sosial Bandung. Diakses dari

https://staff.blog.ui.ac.id > teguh1 > files > 2009/01 > seminar_stks_tk

Kusumayanti, Ni Putu Ari.,Triaryati,Nyoman. 2018. Pengaruh Pendapatan Asli Daerah terhadap Pertumbuhan Ekonomi di Wilayah Sarbagita Provinsi Bali. E-jurnal Manajemen Unud,7(5), 2592-2620. Diakses dari
https://doi.org/10.24843/EJUNUD.208.v7.i 05.p12

Lakoy,Toar Waraney.,Engka, Daisy

S.M.,Tumangkeng, Steeva Y.L. 2016.

Kontribusi dan Pengaruh Penerimaan

Retribusi Daerah terhadap Pendapatan Asli

Daerah di Kabupaten Minahasa. Jurnal

Berkala Ilmiah Efisiensi, 16(1), 559-567.

Diakses dari

https://ejournal.unsrat.ac.id/index.php/jbie/ article/view/11067

Nasir, Muhammad Safar. 2019. Analisis Sumber-sumber Pendapatan Asli Daerah Setelah Satu Dekade Otonomi Daerah. Jurnal Dinamika Ekonomi Pembangunan, 2(1), 30-45. Diakses dari https://ejournal.undip.ac.id/index.php/dina mika_pembangunan/issue/view/2619

Putra, Rico.,Hidayat Surya. 2016. Tingkat Kemandirian Keuangan Daerah dan Hubungannya dengan Pertumbuhan Ekonomi Provinsi Jambi. Jurnal Perspektif dan Pembangunan Daerah, 3(4), 243-256. Diakses dari https://onlinejournal.unja.ac.id/JES/issue/view/554

Riftiasari, Dinar. 2018. Analisis Kontribusi Pajak Daerah dan Retribusi Daerah terhadap Peningkatan Pendapatan Asli Daerah Provinsi DKI Jakarta. Jurnal AKRAB JUARA, 3(3), 190-200. Diakses dari

http://akrabjuara.com/index.php/akrabjuara/ article/view/286/217

Syaifuddin.,Emilia.,Nurjanah, Rahma. 2014. Analisis Tipologi Pertumbuhan Sektor Ekonomi Basis dan Non-Basis dalam Perekonomian Provinsi Jambi. Jurnal Paradigma Ekonomika, 9(2), 1-8. Diakses dari https://onlinejournal.unja.ac.id/paradigma/issue/view/37 7

Saputri, Intan., Boedi, Arfida. 2018. Analisis Sektor Ekonomi Unggulan Pada Kabupaten/Kota di Provinsi Sumatera Selatan. Jurnal Ilmu Ekonomi, 2(2), 217$229 . \quad$ Diakses dari http://ejournal.umm.ac.id/index.php/jie

Setiono, Hari. 2018. Kontribusi Pajak Daerah dan Retribusi Daerah terhadap Pendapatan Asli Daerah di Provinsi Jawa Timur. Prive, 
1(1), 22-28. Diakses dari http://ejurnal.unim.ac.id/index.php/prive

Suci, Cahaya Stannia.,Asamara,Alla. 2014. Pengaruh Kemandirian Keuangan Daerah Terhadap Pertumbuhan Ekonomi Kabupaten/Kota Provinsi Banten.Jurnal Ekonomi dan Kebijakan Pembangunan, 3(1), 8-22. Diakses dari http://journal.ipb.ac.id/index.php/jekp/issue /view/2019

Sulistiyanto, Adi. 2018. Analisis Pajak Daerah dan Retribusi Daerah Provinsi Jawa Tengah. EFFICIENT, 1(3), 214-223. Diakses dari https://doi.org/10.15294/efficient.v1i3.2787 5

Tarmizi, Rosmiaty. 2010. Pendapatan Asli Dae4rah Berdampak pada Kemandirian Keuangan Daerah. Jurnal Akuntansi \& Keuangan, 1(1), 123-128. Diakses dari http://jurnal.ubl.ac.id/index.php/jak/article/ view/13

Tresnawati, Rina.,Putri Erinisia aini.2017. Tinjauan atas Retribusi Daerah terhadap Pendapatan Asli Daerah Pemerintah Kota Bandung. Jurnal ASET (Akuntansi Riset) 9(2), 73-80. Diakses dari https://ejournal.upi.edu/index.php/aset/artic le/view/9228/5831 